\title{
Does Decentralisation Matter to Regional Inequalities? The Case of Small Countries
}

Carlos Gil, Roberto Escurra, Pedro Pascual and Manuel Rapún Gárate

Departamento de Economía, Campus de Arrosadía

Universidad Pública de Navarra

31006 Pamplona (SPAIN)

Telephone: 0034948169346

Fax: 0034948169721

e-mail: cargil@unavarra.es, ppascual@unavarra.es,mrapun@unavarra.es 


\begin{abstract}
This paper analyses the impact of fiscal and political decentralisation and other political conditions on regional productivity inequalities. Although the influence of decentralisation on economic growth has received some attention form researchers in recent years, very few studies deal with its impact on regional inequalities. We analyse the relationship between different measures of regional inequalities in productivity, and various dimensions of political and fiscal decentralisation for a sample of nineteen OECD countries. It could be argued, however, that decentralisation is more relevant in large countries, where political power could be far removed (not only in distance, but also in other economically relevant senses) from peripheral regions. To check this hypothesis we will, in addition, work with a reduced sample of small countries, while controlling for other possible influences by widening the analysis to includes measures of public sector size and the type of governing party.
\end{abstract}

The results suggest a strong negative correlation between decentralisation, mainly fiscal decentralisation, and regional inequalities, which holds almost invariably for the reduced sample of small countries. 


\section{Introduction: politics and economic performance}

Although most economic growth theories have concentrated on capital and technology, there is a rich tradition in the analysis of non-economic factors of growth. Schumpeter (1954), for example, draws special attention to the role of entrepreneurship in generating wealth with his notion of creative destruction. Kuznets (1966) studies the influence of factors such as social and political structure. Development economists like Myrdal (1957) suggested the relevance of political conditions in the study of growth.

It is in the last two decades, however, that there has emerged a widespread and increasing interest in the relationship between politics and political conditions on the one hand and economic performance on the other. Aspects such as political stability, the size of the public sector or fiscal policy measures are becoming common in growth regressions. Barro $(1990,1991)$ is one of the social scientists that have paid more attention to the relationship between political conditions and economic growth. However, in most models, which are embedded in the neoclassical economic theory, social and political factors play only a secondary role, capital accumulation being the main driving force for growth. In this context, few political and social indicators are robustly correlated with growth (Levine and Renelt, 1992). But the fragility of the results concerning social, institutional and political indicators may well be due to this supporting role (Rodriguez-Pose, 1998). The presence of capital investment or capital stock variables may well distract from the relevance of social and political indicators. The close correlation between productivity or productivity growth (the endogenous variables), and capital stock or capital investment (the main exogenous variables), which are directly related and are probably, both the cause and the result of economic growth, may distract from the relevance of those variables that create the conditions needed to fuel a virtuous circle of growth and investment. Thus, Rodriguez-Pose 
(1998) argues that there is a need to consider social political and even cultural factors as principal actors in the process of economic growth.

National economic performance have usually being identified with national growth. But most countries pursue other relevant economic objectives, such as reducing personal and regional inequalities in income or productivity. In the last decade, especially since the publication of the article by Barro and Sala (1991), and in an attempt to test the neoclassical growth theory, there has been a marked increase in the number of studies analysing regional disparities. The main aim in most of these works was not to explain their level or their evolution, but to prove or reject the hypothesis of productivity convergence predicted by the neoclassical model. Institutional, political or social variables were usually omitted in this kind of study, where it was argued that regions within a country share common political and social institutions.

In this chapter we will try to analyse the influence of some potentially important political variables in the degree of regional inequality among OECD countries. We will focus mainly on decentralization, both political and fiscal, but we will also include two other potentially relevant groups of variables. The first refers to the size of the public sector or its economic impact, the second to the nature of its governing political parties.

A second objective is to ascertain whether main conclusions drawn for the full sample are also true for small countries, defined in terms of population and surface. We think that there are some quantitative, and perhaps qualitative, differences (related to the size of the country) that may generate diverse patterns in the object of our study related to the size of the country.

This chapter continues by examining the debate over the different types of outcome that decentralization could help to generate in economic 
performance in general, and regional inequalities in particular. We also discuss arguments that could help to explain a potentially different impact of decentralization in small countries. Section 3 deals with the possible influence of other political variables, namely public sector size and parties in government, on regional disparities. This is followed in section 4 by an explanation of the different measures of regional inequality, decentralization and the remaining political variables that we use in the analysis. Empirical results are given in section 5 . This is followed by a brief concluding section.

\section{Decentralization and economic performance: theoretical and} empirical background

For more than two decades, there has been an increasing interest in decentralisation all around the world. Many developing countries have embarked, or intend to embark, on some form of transfer of political power to local government (see, for example, Dillinger, 1994). Furthermore, decentralisation has become a central issue in the political agenda of developed countries with more consolidated political systems. Belgium became a federal state in 1993 (Oates, 1999). In the UK and Spain decentralisation is an ongoing process, though not without some measure of controversy. In the EU the regions are increasingly perceived to be the relevant units for implementing political decisions (Tomaney and Ward, 2000).

There are numerous reasons that might explain this increasing interest in decentralisation. Some of them were identifies by Armstrong and Taylor (2000). Firstly, the belief in decentralisation as an effective tool for increasing the efficiency of public expenditure. Secondly, the reaction against large centralised bureaucracies in areas such as the EU. The third has to do with the influences of changes that have taken place over the last decades in the way private corporations are managed. The fourth argues that policies designed to stimulate indigenous growth (through the 
encouragement of small firms, for example) are very difficult to run from the centre. Fifth, and last is the demand for a closer democracy, which could promote public participation in social policy and administration (Tunstall, 2001).

Within the main line of comparative political research with an interest in the consequences of federalism and decentralisation there is agreement over the importance of decentralisation issues. Some authors have claimed federalism to be superior to other democratic systems, because it provides a better safeguard for the democratic rights of citizens in general and minorities in particular (Elazar, 1995). Neo-institutionalist economists have also made the case that certain institutional arrangements encourage individuals to engage in some economic activities more than in others, thereby giving rise to more successful economies (North, 1990).

It is widely accepted that the three main objectives of the public sector are those initially stated by Musgrave (1959): efficiency in the allocation of resources, income redistribution and macroeconomic stability. Traditionally, most public economists have agreed that while the first of these functions can be assigned to lower levels of government, the latter two should more appropriately be assigned to the national level. Decentralisation may generate more efficiency, but may also reduce economic stability and aggravate regional inequality. Thus, in recent years these assumptions have provoked considerable controversy.

Emanating from the public choice theory, with roots in the neoclassical school of thought, there is a suggestion that decentralisation could improve efficiency in the allocation of resources by better satisfying the needs and preferences of local citizens, through better knowledge of these preferences (Oates, 1972). These gains in efficiency would be enhanced with mobility of citizens who could choose to live in the jurisdiction that best matched their preferences. Regions would also have incentives to 
compete with one another by attracting migrants, making more efficient use of their resources and increasing economic welfare.

However, some authors (Prudhomme, 1995, Tanzi, 1996) think that preferences among individuals living in a country are quite similar, and that lack of co-ordination among regional governments could reduce efficiency in the provision of some public services. The existence of regional 'spillovers' in the provision of some public goods could also generate an inadequate level of provision.

Keynesian thought supports these arguments. Decentralisation reduces the capacity of central government to use demand policies to alleviate the effects of fluctuations in production and employment. Federal and highly decentralised states would therefore perform worse. Greater centralisation also permits more efficient determination of macro-economic objectives, less diffusion in the utilisation of policy instruments, and a higher degree of co-ordination.

\section{Regional inequalities and decentralisation}

The second main drawback traditionally attributed to decentralisation is an unbalanced distribution of resources across regions that might generate increasing economic differences among them. There are several issues that might influence the final outcome. The first is whether or not decentralisation results in more unequal distribution of public resources. Prudhomme (1995) argues that centralised public sectors will attempt to produce a more balanced distribution by channelling resources from richer areas to poorer ones. Conversely, centralised systems may create unequal distributions of public resources by favouring politically important jurisdictions. The second issue relates to whether centralisation could lead to a higher concentration of private investment. Investors seeking closer ties with politicians and the administration might tend to choose capital regions. 
The third point is that decentralisation can provide sub-national officials with the power to actively pursue economic development policies. This will include not only policies better suited to local needs or capabilities, but also several forms of competition among regional and local governments, which may include granting tax privileges and offering other forms of assistance to businesses willing to locate in a particular jurisdiction (Martinez and McNab, 2001). It is difficult to assess whether or not they will contribute to reducing regional disparities.

Both lines of argument linking political and fiscal decentralisation and economic performance could also be applied to the level of regional disparities. On the basis of the public choice theory, we might expect less regional disparity in decentralised states. In the first place, the power to control most of the public budget locally could generate more competitiveness among regions, forcing regional governments to deliver services at minimum cost, thus enhancing efficiency. Besides, local governments could be removed if they failed to achieve standards of wealth and economic growth similar to those in the rest of the country. The power to design regional policies tailored to local needs, in an effort to promote employment and productivity, would give local officials the capacity to achieve economic goals. Furthermore, as central government would be more reduced in size, the concentration of political and economic power around the capital region would also be less intense.

From a Keynesian approach, however, the weaker central state would play a less crucial role in redistributing income among regions, and could not use demand-side policies, such as public investment, to promote economic growth in the poorer regions. More diffusion in policies such as education or health could also lead to an increase in disparities among decentralised countries. Related to this is the fact that the benefits of regional policies spill over into other areas. For example, the creation of 
extra jobs in an assisted region will reduce the amount of unemployment transfers and raise tax revenue, to the benefit of the inhabitants of nonassisted regions (Armstrong and Taylor, 2000). Other less tangible benefits, such as those of a social or environmental nature, could also spill over the regional boundary. Since there are effects that spread beyond regional borders, totally isolated development policies are likely to produce inefficient levels of regional policy and equalisation among regions.

The two opposing arguments about the impact of decentralisation on regional inequalities sheds no light on the issue that provides the focus of this study: are regional inequalities in decentralised countries greater than, smaller than, or more or less the same as in centralised countries?

We should seek the answer to this question in practical studies. There are hardly any that address this question directly, however. Some national studies (Freinkman and Yossifov, 1999, for Russia) in countries involved in asymmetric devolution processes find better economic performance in regions with more autonomy. However, it has already been mentioned that another study (Zhang and Zou, 1998) yields the opposite result for China. Tsui (1996) directly addresses the issue of regional inequalities and decentralisation. He finds fiscal decentralisation in China to be related to the rise in disparities in the 1980s. Again though, very special circumstances prevailed during this period of analysis, such as the high level of foreign direct investment in the Special Economic Zones, which are to be found in the richest areas ${ }^{1}$. Also, the devolution process in China is asymmetric, thus leaving some regions with more political and fiscal autonomy than others.

\footnotetext{
${ }^{1}$ Zhao and Tong (2000) argues that the "get rich first" policy and "coastal development strategy" has contributed largely to the increase in spatial disparities.
} 
Why small countries could be different?

The second objective of this chapter is to see whether the different indicators of decentralisation, and the two other political variables that will be presented in the next section, have a distinct impact in small countries. There are several reasons that could justify a divergent result to that obtained with larger countries.

First of all, decentralisation could be less relevant when the political and administrative centre is close to all regions of the country. Politicians in central government may be more aware of regional peculiarities and problems when there are fewer regions (which is the case in small countries) than when there are many. Furthermore, the hypothesis that preferences among individuals living in a country are fairly similar (Prudhomme, 1995, Tanzi, 1996) could be particularly true when referred to countries with less diversity $^{2}$.

In large countries, meanwhile, a single region may be large enough to create the appropriate conditions to attract investment or to generate endogenous growth. In small economies, if local markets are too narrow in terms of consumption and employment, peripheral regions could face serious difficulties in trying to compete. Investment would tend to concentrate in central regions, those most densely populated and those that house the country's administrative centres. Centralisation would cause economic activity to concentrate close to where political power was located, thus causing even greater aggravation of inequalities than in larger countries.

\footnotetext{
${ }^{2}$ Although it is not immediate that small countries, characterised in terms of population and/or surface, are less diverse in terms of economy, culture, natural resources, etc (Switzerland or Norway could be good counter-examples) we can expect a smaller average degree of diversity.
} 
Finally, the answers to the questions about the influence of decentralisation on regional disparities, and about the possibility of a different outcome of decentralization depending on the size of the country, can only be answered through empirical work. We will initiate the research for the answers to these questions after introducing the other variables that we will consider in our analysis.

\section{Public sector size and parties: their influence on regional} disparities

Although the main purpose of this study is to check the influence of different indicators of decentralisation on regional disparities, we will also deal with other political variables, namely those relating to the size of the public sector and the political orientation of the parties in power. The main reason for this is that the omission of potentially relevant variables, especially those that could be correlated with decentralisation, could bias the results. Also, as we are about to explain, there are reasons to suspect that both the size of the public sector and the partisan influence could be correlated with decentralization.

\section{Decentralisation, public sector, and regional disparities}

The 'hypothesis of decentralisation', proposed by Brennan and Buchanan (1980), suggests that decentralisation increases competitiveness among local governments and restrains the growth of the public sector. This hypothesis has been tested by Cameron (1978) Oates (1985), Heil (1991), Pierson (1995) and Lane and Ersson (2000) among others. Most of them have found a positive relationship between decentralisation and public sector size when the analysis includes only developed countries. If both variables are related, the size of the public sector should be included in the analysis in order to avoid the problem of omitted explicative variables. 
There are two opposite lines of arguments that could explain the role of the public sector in regional disparities. The first of these would support the hypothesis that a larger public sector could help to reduce inequalities. A public sector with more capacity to fund regional policies could activate the lagging regional economies through subsidies, or infrastructure investment, or financing human capital formation, for example. This type of support would have a long-term impact on regional productivity and employment. Larger public sectors also have larger social security systems. Public pensions and unemployment benefits reduce disposable income disparities, and may indirectly generate less divergence in terms of employment and productivity in the non-tradable service sector of the poorer regions. Public service salaries are usually similar in all regions, thus high numbers of civil service employees, for example in a public health system or in education, could also help to reduce disparities.

The second argument favours the increasing of disparities, both in productivity and income per capita. Extensive public support for entrepreneurship and the unemployed in the form of subsidies generates fewer incentives to increase the competitiveness of existing firms, to increase human capital or even to accept low-paid jobs. As the lagging regions are the more seriously affected by unemployment and lack of competitiveness (usually in decaying industries), net transfers from the more developed regions could delay the inevitable restructuring of the region.

Parties in government, public sector, and regional disparities

According to the hypothesis of partisan influence on public policy, the existence of a left/right alternative leads to the application of different policies, with different political and economical outcomes. This hypothesis, which is based on the theory of a democratic political market, has been developed mainly in contributions to empirical democracy theory and 
research on partisan effects, like those of Castles (1982), Hibbs (1987a,b, 1992), Alesina and Roshental (1995) or Schmidt (1996).

Although cross section national studies have not yielded conclusive results when studying the linkages between the party composition of government and macroeconomic indicators ${ }^{3}$, the analysis of country case studies (for example, Hibbs, 1987b, for USA) and comparative research (Castles 1989) support the hypothesis of partisan influence. According to Hibbs (1987a, 1987b), economic policy and macroeconomic outcomes such as unemployment and inflation are largely linked to the left or right wing tendency of governments, with the left more intent on pursuing lower unemployment levels, while the right puts more effort into controlling inflation. The increase in public spending in the post-1960 period is also clearly related to the participation of leftist parties in government (Schmidt, 1996). The correlation between public sector size and growth, and the support found in the literature for the hypothesis that partisan influence on public policy could influence economic outcomes in advanced democratic states, suggest the need to introduce measures of the party composition of government in our analysis.

There are arguments linking regional inequalities with public sector size that could also be adapted to relate regional inequalities to partisan influence. First, the strength of the conservative parties is associated with a weaker social policy. This could lead to an increase in regional inequality resulting from the reduction of transfers to the unemployed (if the lagging regions are the ones with higher unemployment), or more differences in education and health systems, with impact both in the long run (larger disparities in human capital) and in the short run (reduction of the equalising effect of civil service salaries). Implications of the opposite nature,

\footnotetext{
${ }^{3}$ See Schmidt (1996) for a review of this type of studies.
} 
meanwhile, could be related to the presence in government of parties with a more market-oriented ideology (conservatives and liberal) which could reduce the incentives to remain unemployed in the less developed regions, thereby increasing migration (which could help to reduce unemployment and increase per capita capitalisation) and encouraging the mobilisation of endogenous factors.

The impact of both the weight of the public sector in the economy and the party in power in regional disparities could also differ depending the size of the country. For example, unemployment benefits are related to both larger public sector size and the presence of left parties in government. And this income could generate larger distortions in small countries, where barriers to mobility of the work force could be less relevant, than in large ones.

4. Measures of regional inequality, decentralisation, public sector size and parties in power

\section{Measures of inequality}

We will use measures of regional disparities in GDP per worker (GDPpw). Other measures of affluence, such as GDP per capita (GDPpc), are less appropriate for this type of study, because the existence of commuters produces great distortion in some regions. Clear examples of this are Hamburg and Bremen in Germany, the District of Columbia in the USA, and Oslo in Norway. Another disadvantage of GDP per capita is that it is influenced by the age structure of the population and activity rates.

In some countries, mainly federal states, such as Germany or USA, the relevant level of regional aggregation is quite clear. In others, such as France or the UK, this could pose a problem. In these countries, the use of NUTS1 or NUTS2 levels, giving the same weight to all regions, could lead to widely differing results. We will use inequality indices weighted by 
employment, so that the level of aggregation does not heavily influence the results (Esteban, 1994).

It is well known that different indices of inequality are based on alternative ethical assessments. By calculating alternative indices and using them in the analysis, it is possible to ensure that differences between countries are real, and the results robust. In this chapter we will use 'sigma', the standard deviation of the natural logarithms of the GDP per worker, a measure that has become widespread in the analysis of regional disparities in the convergence literature, and also three other measures: Gini, Theil and Atkinson indices. These are more common in the analysis of interpersonal income disparities, but they have been employed in studies dealing with regional inequalities (Tsui, 1996, and Esteban, 1994). All of them satisfy the Dalton transfer principle, that is, a transfer from a richer to a poorer region reduces inequality, but they have different degrees of sensitivity. Some of the indices have a high degree of "inequality aversion", thus an increase in the value of a very poor region would have a very large impact in the index. Other have less inequality aversion, thus an increase in the value for a very poor region would have almost the same impact in the index as that of a region slightly below average ${ }^{5}$.

Atkinson index, $\mathrm{A}(\varepsilon)$, is really an infinite set of indices, which ranks from "none" to "very high" inequality adversity. A low value of the parameter $\varepsilon$ indicates low inequality aversion (with $\varepsilon=0, \mathrm{~A}(0)=0$ ). We will calculate Atkinson indices with three different levels of aversion: $\mathrm{A}(1)$ has a

\footnotetext{
${ }^{4}$ When the relevant unit is controversial, like in the UK, we have made all the calculations with NUTS 1 and NUTS2 with little significant differences to results.

${ }^{5}$ For a detailed analysis of the properties of the various measures of inequality, see, for example, Champernowne and Cowel (1998).
} 
low aversion to inequality, $\mathrm{A}(3)$ with a medium aversion, and $\mathrm{A}(21)$ with high inequality aversion.

We will present the results for two different samples. The first includes all the OECD countries for which we have been able to gather data on regional GDP and employment, and indicators of decentralization, public sector size and partisan influence. This means that we have data for nineteen countries. The second is a sub-sample of eleven small countries. The distinction could pose problems, but in our case is quite evident that there is a clear cut between Spain (with the smallest population and GDP among the large countries) and the Netherlands (the largest among the small countries in this two indicators). With this distinction we aim to test the hypothesis of the relevance of size when analysing the influence of decentralisation.

In order to avoid distortion in GDPpw generated by the economic cycle, we calculate the indices for the average of the period 1990-1997. Table 1 shows the results of these indices.

\section{[Insert table 1 around here]}

The countries that show the greatest regional inequality on most of the indices are Portugal, France, Japan, Italy and Spain. A(21), however, produces quite a different ranking. On this index, Japan, Italy and Spain continues to register the highest regional inequality, but France and Portugal improve considerably. The countries with the least regional inequality are Germany, Sweden, the Netherlands and Switzerland. These indices suggest a relationship between federalism and regional inequalities that we will attempt to confirm in section 5 .

On the whole, the ranking is quite similar on all the indices, with the exception of $\mathrm{A}(21)$. This idea is further confirmed by the correlation coefficients for these indices, which are shown in table 2. All are very high, 
except those that include $A(21)$, an index which is highly sensitive to small incomes, regardless of the size of the region.

\section{[Insert table 2 around here]}

\section{Measures of decentralisation}

Next we present a group of variables that can be used to measure decentralisation. As Martinez-Vazquez and McNab (2001) have stated, this is a problematic issue, because there is no single or best measure of decentralisation. A country may allocate a large fraction of the public budget at regional level but regions may lack sufficient autonomy to make decisions on expenditure. It is therefore important to test several alternative measures of decentralisation.

Nine measures of decentralisation are featured in table 3. Sources and notes to this table provide precise details of each variable. Since the first five variables focus on political issues, we consider them to be indices of political decentralisation. The last four concentrate on revenues or expenses, thus we call them indices of fiscal decentralisation.

The first measure, Federalism, is a dummy variable that takes the value 1 when the country has a federal constitution. Only four countries have been federations for a relevant period of time. Belgium became federal in 1993, but this is too late for it to have had any impact on regional disparities. The next four variables (Constitutional Structure, Lijphart index, Institutional Pluralism, and Institutional Constraints) measure levels of political restraint to central government intervention. The Lijphart indices are standardised arithmetic means of $\mathrm{z}$-transformed indicators of the federalism-unitarism dimension. The other three variables are additive indices.

Fiscal Difficulty measures the capacity of central government to influence economic performance. Fiscal Decentralisation measures the share 
of regional and local taxes in total revenue. Fiscal Centralisation measures the share of central government revenue in total revenue, excluding supranational and social security taxes, so it is not the mirror image of Fiscal Decentralisation. The reason for excluding these taxes is that central government experiences more difficulty in manipulating these revenues than other taxes under its direct control. The last variable, Financial Autonomy, measures the proportion of local and regional government final consumption in relation to general government final consumption. This variable focuses on expenses, whilst the previous two focus on the revenue side.

\section{[Insert table 3 around here]}

\section{Measures of public sector size and parties in power}

Mention has already been made of previous studies that have found a positive correlation between public sector size and centralisation (at least for developed countries). The detected relationship between regional inequalities and decentralisation may be a spurious correlation, the significant one being the relationship between public sector size or parties in government and productivity inequalities. Table 4 includes 3 variables that measure public sector size, and three others that measure the government profiles.

\section{[Insert table 4 around here]}

\section{The results}

We begin our research by analysing correlation between the different measures of decentralisation and the alternative indices of regional inequality. As can be seen in table 4 , there is negative correlation between decentralisation and regional inequality. The exceptions are IP and "fiscal difficulties" which present contrary signs for some of the inequality indices, although at insignificant levels. Fiscal difficulties is a variable with no clear relation to fiscal decentralization, and its construction is so clearly open to 
criticism, that this result is not surprising. Be aware that with the Lijphart and Fiscal Centralisation indices a positive coefficient supports the hypothesis of a negative relationship between decentralization and greater regional disparities, although in most cases it is not significant.

The only highly significant indices are Fiscal Decentralization and specially Financial Autonomy (\% of local and regional government consumption in relation to general government consumption). These results may indicate that federalism and decentralisation matter, but only if they lead to greater regional fiscal powers. In the following pages we will try to confirm this first result by introducing new variables into the analysis ${ }^{6}$.

The results for the small countries are similar to those obtained for the full sample. Correlation coefficients are even higher and present the expected sign, although the reduction in the sample means that significance levels do not improve. Again, Fiscal Decentralization and Financial Autonomy are highly significant.

\section{[Insert table 5 around here]}

Graph 1 shows the relationship between the most significant measure of decentralisation (Financial Autonomy) and sigma for both the small and

\footnotetext{
${ }^{6}$ We have also checked correlation with other variables that could influence the results, as total GDP, GDPpc, population and average population per region, surface and average surface per region, and the number of regions. The correlation of the relative variables (GDPpc, average population and surface of the regions) with the inequality indices are very close to 0 . The variables related to the size of the country (total GDP, population, surface and the number of regions) are slightly correlated with inequality. Thus, there are signs that small regions could be different. In the regressions that follow we have also included the number of regions of the country (the variable with higher correlation with the inequality indices), but the results are not reported, because this variable is not significant and the main results are not altered.
} 
the large countries. As can be seen, the relationship is very similar, but it is more significant for the small countries sample.

\section{[Insert graph 1 around here]}

Table 6 shows the correlation of the public sector and party in government variables with the inequality indices. Coefficients between variables related to public sector size and those that measure regional inequality are lower than those reported between decentralisation indices and regional inequality, but still favour the hypothesis that a larger public sector could help to reduce disparities. The presence of leftist parties in government is also negatively correlated with the degree of inequalities, with significant values for Left $\%$ and Left index. The values for the coefficients of the reduced sample are in this case lower, although they also suggest a positive influence of left wing parties in reducing disparities.

The preliminary conclusion of this survey is that the relationship between decentralisation and regional inequality does not appear to be a spurious correlation resulting from the omission of variables controlling for the size of the public sector or political orientation of parties in government. This is because correlation is stronger with decentralization (at least fiscal decentralization) than with the other two groups of political indices. In the following pages we will continue our analysis of this relationship, using the multiple regression technique.

\section{[Insert table 6 around here]}

Multivariate analysis is restricted because of the small size of the sample. Nevertheless, it is worth testing to see if the previous relationships are still valid when more than one variable is included at a time. We have regressed the different measures of regional inequality as dependent variables, and the three types of independent variables. We have regressed all possible combinations of the nine variables measuring decentralisation, 
the three measuring Public Sector, and the three partisan variables. We will show in table 7 the results of some of these regressions, including in all the cases a measure of decentralisation and either an index of the size of the public sector or (alternatively) an index of parties in power ${ }^{7}$. We do not present the results for the threes types of variables in the same regression because the variables that measure public sector size and parties in government are significantly correlated ${ }^{8}$.

\section{[Insert table 7 around here]}

Results are quite encouraging. The signs obtained for all the variable supports the positive influence of decentralisation in helping to reduce regional inequalities. Larger public sector size and the presence of leftcentre parties in government also seem to favour minor disparities.

When A(1) (small risk adversity) and Sigma (medium adversity) are introduced as endogenous variables, Fiscal Decentralization and Financial

\footnotetext{
${ }^{7}$ Results of the regressions when the endogenous variables are Gini and $\mathrm{A}(3)$ are very similar to those obtained with Sigma, thus they are not included here. Results with Theil index are somewhere in between those obtained with $\mathrm{A}(1)$ and Sigma. Among the decentralisation variables, we have selected Federal (which is not comparable to any other variable), and Lijphart and IC (because they are conceptually similar to CS and IP, and are slightly more significant in most regressions). We also present the results for PSS and GFE/GDP, excluding OPE/GDP, because the results for this variable are similar to those obtained with PSS but slightly less significant. Among the parties in government variable, Left $\%$ produces similar results to those obtained when the Left index is included in the regressions, and it is clearly more significant than $\mathrm{L} / \mathrm{R}$ scale.

${ }^{8}$ For example, the correlation coefficient between Left $\%$ and PSS is 0.489 , between Left $\%$ and Fiscal Decentralisation is 0.02, and between PSS and Fiscal Decentralisation is 0.019. We have also estimated regressions with the three types of variables, and tested the results for multi-collinearity (using the Farrar-Glauber test). The result show that there is a problem of multi-collinearity between public sector size and parties in government (but not with decentralisation).
} 
Autonomy are significant at levels even below $1 \%$. Left $\%$ is significant in all the regressions, whilst results for public sector variables are better when including GFE (as percentage of GDP) than when including PSS. Financial Autonomy is the variable that produces the highest adjusted $\mathrm{R}^{2}$, indicating the relevance of regional spending in the process of keeping regional disparities low.

If $\mathrm{A}(21)$ is introduced as endogenous variable, results change slightly. Decentralisation variables and Left\% are less significant, and PSS is more relevant. We must keep in mind that this index is mainly determined by the distance between the poorest region and the average, with minor relevance of regional size and the rest of the units. In this situation, the existence of a large welfare state could be important in alleviating the economic situation of small regions that are lagging behind.

$\underline{\text { We have also tested for differences between large countries and small }}$ countries, performing the LM test of structural change (table 7). There is no evidence that could lead us to suspect that the results are not valid for the sub-sample of small countries. Table 8 shows that the results for the sample of Small Countries. We reproduce only those with fiscal variables, as they have proved the most relevant. These results should be interpreted with great care because of the obvious problem of the lack of degrees of freedom. Again, we obtain some remarkable results. We might expect a decrease in the significant levels of the decentralization variables, because of the rise in the standard deviations of the errors, but both are significant. Estimated values are higher than in the full sample, suggesting that the role of decentralization in reducing regional disparities is even more important in the small countries. However, the other two groups of variables (public sector size and partisan variables) are less significant, although still with the expected sign.

\section{[Insert table 8 around here]}




\section{Conclusion}

The main conclusion that may be drawn is that decentralisation, and especially fiscal decentralisation, appears to be linked with lower regional disparities in labour productivity. The relationship between decentralisation and regional equality does not weaken when other explanatory variables related to public sector size and parties in government are included.

Also remarkable is the difference in results that we obtain from different measures of decentralisation. The most significant, which also gives the highest adjusted $\mathrm{R}^{2}$, is the one most closely related to fiscal decentralisation. Castles (1999), in his analysis of the link between decentralisation and economic performance in a sample similar to ours, also found evidence to support the hypothesis that it is fiscal decentralisation rather than political structure that matters.

The consequences of political and fiscal decentralisation are not merely a question of academic concern. Reduction of regional inequalities is one of the most important issues in the regional policy of the EU. If changes in the administrative level at which certain political and budgetary decisions are taken can help to reduce inequalities, it would matter, not merely in the sense that we would know more, but in the sense that we could do more.

Our results suggest also a positive relationship between larger public sector and the presence of left and centre parties in power and a lower degree of regional inequalities.

A second objective of this chapter was to ascertain whether the influence of political factors, particularly decentralisation, on regional disparities could be different in small countries. There were some arguments that might generate doubts about the relevance of the geographical distribution of power in these states. Our results, however, suggest that we can expect decentralisation to have the same degree of positive influence, if 
not more, in small as in large countries. Although the likelihood of federal governance in small countries could be limited (but not impossible: Switzerland is a federal state), fiscal decentralization can be achieved without federalization, as the case of Sweden shows. Perhaps devolution to local administrations, instead to regional ones, can be the most reasonable way to locate power close to the citizens and, hopefully, reduce regional disparities in small countries. 


\section{REFERENCES}

ALESINA, A. and ROSENTHAL; H. (1995) Partisan politics, divided government, and the economy. Cambridge: Cambridge University Press.

ARMSTRONG, H. and TAYLOR, J. (2000) Regional Economics and Policy. Oxford: Blackwell Publishers.

BARRO, R.J. (1990): Government Spending in a Simple Model of Economic Growth, Journal of Political Economy 98-2, pp. 103-125.

BARRO, R.J. (1991): Economic Growth in a Cross-Section of Countries, Quarterly Journal of Economics 1062, pp. 407-443.

BARRO, R.J. and SALA-I-MARTÍN, X. (1991): Convergence Across States and Regions, Brooking papers on Economic Activity 1, pp.107-182.

BRENNAN, G. and BUCHANAN, J.M. (1980) The power to tax. Analytical foundations of a fiscal constitution. Cambridge: Cambridge University Press.

CAMERON, D. (1978) The Expansion of the Public Economy: A Comparative Analysis, American Political Science Review 72-4, pp. 12431261.

CASTLES, F. (1982) The impact of parties. Politics and policies in democratic capitalist states. London: Sage Publications.

CASTLES, F. (1989) The comparative history of public policy. Cambridge: Polity Press.

CASTLES, F. (1999) Decentralisation and the Post-war Political Economy, European Journal of Political Research, 36-1, pp. 1-26.

CHAMPERNOWNE, C. and COWEL, F. (1998) Economic inequality and income distribution, Cambridge University Press, Cambridge. 
COLOMER, J. (1995) Introducción, pp- 7-25 in J.M. Colomer (ed.) La política en Europa, Ariel, Barcelona.

DILLINGER, W. (1994) Decentralisation and its Implication for Urban Service Delivery, Urban Management Programme Discussion Paper No. 16, World Bank.

ELAZAR, D.J. (1995) Federalism, in S.M. Lipset (ed.) The Encyclopedia of Democracy, London: Routledge.

ESTEBAN, J. (1994): La desigualdad interrregional en Europa y en España: descripción y análisis, in J. Esteban and X. Vives (eds) Crecimiento $y$ convergencia regional en España y Europa, Instituto de Análisis Económico y Fundación de Economía Analítica, Barcelona.

FREINKMAN, L. and YOSSIFOV, P. (1999) Decentralisation in Regional Fiscal Systems in Russia: Trends and Links to Economic Performance World Bank Working Paper 2100.

HEIL (1991) The Search for Leviathan Revisited, Public Finance Quarterly 19, pp. 334-346.

HIBBS, D.A. (1987a) The political economy of industrial democracies. Cambridge: Harvard University Press.

HIBBS, D.A. (1987a) The American political economy. Cambridge: Harvard University Press.

HIBBS, D.A. (1987a) Partisan theory after fifteen years, European Journal of Political Economy 8: pp. 361-373.

KUZNETS, S. (1966): Modern Economic Growth: Rate, Structure and Spread. New Haven: Yale University Press.

LANE, J.E. and ERSSON, S. (2000) The New Institutional Politics. Performance and Outcomes, London and New York: Routledge. 
LEVINE R. and RENELT D. (1992): A Sensitivity Analysis of CrossCountry Growth Regressions, American Economic Review 82-4, pp. 942963.

LIJPHART, A. (1984) Democracies. New Haven and London: Yale University Press.

MARTINEZ-VAZQUEZ, J. and MCNAB R. (2001): Fiscal Decentralisation and Economic Growth, Working Paper 01-1, Andrew Young School of Policy Studies, Georgia State University.

MUSGRAVE, R. (1959) The theory of Pubic Finance, New York: McGraw-Hill.

MYRDAL; G. (1957) Economic Theory and Underdeveloped Regions, London: Duckworth

NORTH, D.C. (1990) Institutions, Institutional Change, and Economic Performance, New York: Cambridge University Press.

OATES, W.E. (1972) Fiscal Federalism Hascourt Brace Jovanovich, New York

OATES, W.E. (1985) Searching for Leviathan: an Empirical Study, American Economic Review 75, pp. 748-757.

OATES, W.E. (1999): An Essay on Fiscal federalism, Journal of Economic Literature 37, pp. 1120-1149.

PIERSON, P. (1995) Fragmented Welfare States: Federal Institutions and the Development of Social Policy, Governance 8, pp. 449-78.

PRUDHOMME, R. (1995) On the Dangers of Decentralisation, World Bank Economic Review 9.

RODRIGUEZ-POSE, A. (1998) The Dynamics of Regional Growth in Europe: Social and Political Factors, Oxford: Oxford University Press: 
SCHMIDT, M.G (1996) When parties matter: A review of the possibilities and limits of partisan influence on public policy European Journal of Political Research 30, pp 155-183.

SCHUMPETER, J. (1954) Capitalism, socialism, and Democracy, $4^{\text {th }}$ edition, London: Allen \& Unwin.

TANZI, V. (1996) Fiscal federalism and Decentralisation: a review of Some Efficiency and Macroeconomic Aspects, Annual World bank Conference on Development Economics, M. Bruno and B. Pleskovic (eds.) pp. 295-316, World Bank, Washington.

TOMANEY, J and WARD, N. (2000) England and the 'new regionalism', Regional Studies, 34-5, pp. 471-478.

TUNSTALL, R. (2001) Devolution and User Participation in Public Services: How They Work and What They Do Urban Studies 38-13: 24952514 .

TSUI, K (1996) Economic Reform and Inter-provincial Inequalities in China Journal of Development Economics 50, pp. 353-368.

ZHANG, T. and ZOU, H. (1998) Fiscal Decentralisation, Public Spending, and Economic Growth in China, Journal of Public Economics 67-2, pp. 221-40.

ZHAO, X. and TONG, S. (2000) Unequal Economic Development in China: Spatial Disparities and Regional Policy Reconsideration, 1985-1995 Regional Studies, 34-6, pp. 549-561. 
Table 1. Different measures of regional inequalities in GDP per worker

\begin{tabular}{|c|c|c|c|c|c|c|c|c|c|c|c|c|}
\hline & \multicolumn{2}{|c|}{ Sigma } & \multicolumn{2}{|c|}{ Gini } & \multicolumn{2}{|l|}{ Theil } & \multicolumn{2}{|c|}{$\mathrm{A}(1)$} & \multicolumn{2}{|c|}{$\mathrm{A}(3)$} & \multicolumn{2}{|c|}{$\mathrm{A}(21)$} \\
\hline & Value & rank & Value & rank & Value 1 & rank & Value & rank & Value & rank & Value & rank \\
\hline France & 0.152 & 18 & 0.132 & 18 & 0.0126 & 18 & 0.0121 & 18 & 0.033 & 18 & 0.106 & 11 \\
\hline Germany & 0.057 & 1 & 0.040 & 1 & 0.0017 & 1 & 0.0017 & 1 & 0.001 & 1 & 0.007 & 1 \\
\hline Italy & 0.138 & 16 & 0.113 & 16 & 0.0089 & 15 & 0.0092 & 16 & 0.029 & 16 & 0.158 & 17 \\
\hline Spain & 0.131 & 15 & 0.107 & 15 & 0.0080 & 14 & 0.0082 & 15 & 0.026 & 15 & 0.179 & 19 \\
\hline UK & 0.100 & 7 & 0.087 & 9 & 0.0050 & 7 & 0.0050 & 7 & 0.015 & 7 & 0.086 & 10 \\
\hline Canada & 0.107 & 10 & 0.089 & 10 & 0.0055 & 8 & 0.0056 & 10 & 0.017 & 10 & 0.144 & 16 \\
\hline US & 0.129 & 14 & 0.105 & 14 & 0.0114 & 17 & 0.0057 & 11 & 0.022 & 14 & 0.121 & 13 \\
\hline Japan & 0.141 & 17 & 0.123 & 17 & 0.0095 & 16 & 0.0098 & 17 & 0.030 & 17 & 0.161 & 18 \\
\hline \multicolumn{13}{|c|}{ Small Countries (SC) } \\
\hline Austria & 0.111 & 12 & 0.093 & 13 & 0.0065 & 12 & 0.0063 & 13 & 0.018 & 11 & 0.076 & 9 \\
\hline Belgium & 0.114 & 13 & 0.087 & 8 & 0.0069 & 13 & 0.0066 & 14 & 0.019 & 12 & 0.073 & 7 \\
\hline Denmark & 0.095 & 6 & 0.092 & 12 & 0.0047 & 6 & 0.0046 & 6 & 0.013 & 6 & 0.055 & 5 \\
\hline Finland & 0.072 & 5 & 0.064 & 5 & 0.0027 & 5 & 0.0026 & 5 & 0.008 & 4 & 0.039 & 3 \\
\hline Greece & 0.105 & 9 & 0.074 & 6 & 0.0055 & 9 & 0.0054 & 8 & 0.016 & 9 & 0.121 & 15 \\
\hline Ireland & 0.111 & 11 & 0.091 & 11 & 0.0057 & 11 & 0.0059 & 12 & 0.019 & 13 & 0.121 & 14 \\
\hline Netherlands & 0.065 & 3 & 0.054 & 3 & 0.0021 & 3 & 0.0021 & 3 & 0.006 & 3 & 0.040 & 4 \\
\hline Norway & 0.105 & 8 & 0.086 & 7 & 0.0056 & 10 & 0.0055 & 9 & 0.016 & 8 & 0.076 & 8 \\
\hline Portugal & 0.160 & 19 & 0.154 & 19 & 0.0131 & 19 & 0.0129 & 19 & 0.036 & 19 & 0.120 & 12 \\
\hline Sweden & 0.058 & 2 & 0.049 & 2 & 0.0018 & 2 & 0.0017 & 2 & 0.005 & 2 & 0.023 & 2 \\
\hline Switzerland & 0.072 & 4 & 0.063 & 4 & 0.0025 & 4 & 0.0025 & 4 & 0.008 & 5 & 0.059 & 6 \\
\hline Average & 0.107 & & 0.090 & & 0.006 & & 0.006 & & 0.018 & & 0.093 & \\
\hline Average SC & 0.097 & & 0.082 & & 0.005 & & 0.005 & & 0.015 & & 0.073 & \\
\hline
\end{tabular}

Sources: Cambridge Econometrics, Statistisches Lamdesamt Waden-Wurttemberg (Germany), Statistics Norway, Canadian Statistics, Japan Statistical Yearbook (several years; Statistics Bureau, Management and Co-ordination Agency, Government of Japan), Bureau of Economic Analysis (USA). 
Table 2: Correlation coefficients of the inequality indices

\begin{tabular}{|l|c|c|c|c|c|c|}
\hline & Sigma & Gini & Theil & $\mathrm{A}(1)$ & $\mathrm{A}(3)$ & $\mathrm{A}(21)$ \\
\hline Sigma & - & 0.970 & 0.947 & 0.927 & 0.981 & 0.812 \\
\hline Gini & 0.970 & - & 0.964 & 0.962 & 0.947 & 0.722 \\
\hline Theil & 0.947 & 0.964 & - & 0.965 & 0.975 & 0.694 \\
\hline $\mathrm{A}(1)$ & 0.927 & 0.962 & 0.965 & - & 0.989 & 0.730 \\
\hline $\mathrm{A}(3)$ & 0.981 & 0.947 & 0.975 & 0.989 & - & 0.812 \\
\hline $\mathrm{A}(21)$ & 0.812 & 0.722 & 0.694 & 0.730 & 0.812 & - \\
\hline Average & 0.927 & 0.913 & 0.909 & 0.915 & 0.941 & 0.754 \\
\hline
\end{tabular}


Table 3. Decentralisation measures

\begin{tabular}{|l|c|c|c|c|c|c|c|c|c|}
\hline & Federal $^{1}$ & $\mathrm{CS}^{2}$ & Lijphart $^{3}$ & $\mathrm{IP}^{4}$ & IC $^{5}$ & FiscDif $^{6}$ & FiscDec $^{7}$ & FiscCen $^{8}$ & FinAut $^{9}$ \\
\hline France & 0 & 2 & 0.36 & 3 & 1 & 4.7 & 8.5 & 48.9 & 30.00 \\
\hline Germany & 1 & 4 & -1.79 & 4 & 5 & 6.7 & 30.8 & 33.4 & 77.25 \\
\hline Italy & 0 & 1 & 0.01 & 4 & 3 & 4.4 & 2.6 & 60.8 & 41.25 \\
\hline Spain & 0 & 1 & -0.23 & 3 & 2 & 6.2 & 8.6 & 50.2 & 34.25 \\
\hline UK & 0 & 2 & 1.4 & 1 & 1 & 3.4 & 8.8 & 73.9 & 38.75 \\
\hline Canada & 1 & 4 & -1.22 & 5 & 3 & 5.8 & 44.7 & 43.3 & 69.69 \\
\hline US & 1 & 7 & -1.62 & 6 & 5 & 7.9 & 28.8 & 41 & 50.57 \\
\hline Japan & 0 & 2 & -1.11 & 3 & 2 & 7.3 & 25 & 46.6 & 72.53 \\
\hline & & & & Small Countries & & & & \\
\hline Austria & 1 & 2 & -0.37 & 3 & 2 & 4.2 & 21.6 & 51.8 & 60.25 \\
\hline Belgium & 0 & 1 & 0.19 & 3 & 3 & 3.3 & 4.8 & 62.2 & 26.50 \\
\hline Denmark & 0 & 0 & 0.49 & 2 & 2 & 2.8 & 29.9 & 66.9 & 63.00 \\
\hline Finland & 0 & 1 & 0.46 & 3 & 2 & 3.8 & 24.1 & 59.5 & 63.25 \\
\hline Greece & 0 & 2 & 0.64 & 0 & 1 & 4.5 & 4.3 & 65.7 & 25.25 \\
\hline Ireland & 0 & 0 & 0.76 & 2 & 2 & 3.1 & 4.4 & 82.2 & 48.75 \\
\hline Netherlands & 0 & 1 & 0.33 & 2 & 1 & 3.4 & 10 & 56.4 & 53.50 \\
\hline Norway & 0 & 1 & -0.08 & 1 & 2 & 3.5 & 20.4 & 54.4 & 56.00 \\
\hline Portugal & 0 & 0 & 0.61 & 2 & 1 & 4.3 & 4.4 & 70.1 & 14.50 \\
\hline Sweden & 0 & 0 & -0.06 & 1 & 0 & 3.6 & 32 & 49.2 & 65.25 \\
\hline Switzerland & 1 & 6 & -1.53 & 6 & 5 & 11.3 & 39.9 & 27 & 74.75 \\
\hline Average & 0.26 & 1.95 & -0.15 & 2.84 & 2.26 & 4.96 & 18.61 & 54.92 & 50.80 \\
\hline Average SC & 0.18 & 1.27 & 0.13 & 2.27 & 1.91 & 4.35 & 17.80 & 58.67 & 50.09 \\
\hline
\end{tabular}

Sources and notes:

${ }^{1}$ Federalism is coded: $0=$ no, $1=$ yes, from Castles (1999).

${ }^{2}$ Constitutional Structure, CS, from Schmidt (1996). This variable is an additive index where: federalism $0=$ no, $1=$ =weak, $2=$ strong; $0=$ parliamentary, $1=$ president or collegial executive; $0=$ proportional representation, $1=$ modified proportional representation, $2=$ single-member districts; $0=$ no second chamber or second chamber with very weak powers, $1=$ weak bicameralism, $2=$ strong bicameralism; $0=$ no referendum or very infrequent, $1=$ frequent.

${ }^{3}$ Lijphart index: scale of federalism as developed by Lijphart (1984) and taken from Schmidt (1996). The data are standardised arithmetic means of z-transformed indicators of the federalism-unitarism dimension proposed by Lijphart (1984). Negative values indicate strong decentralisation.

${ }^{4}$ Institutional Pluralism, IP: additive index of constitutional safeguards for sub national governance and modes of representations, based on Colomer (1995), and taken from Schmidt (1996). Composed of 4 indicators (coded 0,1 or 2): number of effective parties, bicameralism, elected president and decentralisation. High values indicate higher barriers against national dominance.

${ }^{5}$ Institutional Constraints, IC: additive index of federal structures, taken from Schmidt (1996). It is an additive index that measures constraints that are due to policy harmonisation in the EU, degrees of centralisation of state structures, difficulty of amending constitutions, bicameralism, central bank autonomy and referendum. Higher values indicate decentralisation

${ }^{6}$ Fiscal Difficulty, FiscDif, is the reduction in central government revenue share that would be required to secure $1 \%$ of GDP increase in demand, as calculated by Castles (1999)

${ }^{7}$ Fiscal Decentralisation, FiscDec, is the share of regional and local taxes in total revenue. Averages from 1973, 1983 and 1992, taken from Castles (1999) and calculated from OECD Revenue Statistics.

${ }^{8}$ Fiscal Centralisation, FiscCen, is central government revenue as a share of total revenue, averages from 1973, 1983 and 1992, taken from Castles (1999) and calculated from OECD Revenue Statistics.

${ }^{9}$ Financial Autonomy, FinAut, measures the proportion of local and regional government final consumption in relation to general government final consumption. Average for years 1960, 1970, 1980 and 1990, calculated from OECD National Accounts (various years). 
Table 4. Public sector size and party orientation variables

\begin{tabular}{|c|c|c|c|c|c|c|}
\hline & \multicolumn{3}{|c|}{ Public Sector Size } & \multicolumn{3}{|c|}{ Party orientation } \\
\hline & $\mathrm{PSS}^{1}$ & GFE/GDP ${ }^{2}$ & $\mathrm{OPE} / \mathrm{GDP}^{3}$ & Left $\%^{4}$ & Left index ${ }^{5}$ & $\mathrm{~L} / \mathrm{R}$ scale $^{6}$ \\
\hline France & 46.8 & 18.3 & 28.7 & 35.1 & 111.3 & 2 \\
\hline Germany & 43.5 & 18.8 & 24.5 & 77.8 & 198.0 & 2 \\
\hline Italy & 42.9 & 16.3 & 29.0 & 90.5 & 201.1 & 2 \\
\hline Spain & 37.2 & 15.1 & 22.8 & 63.6 & 190.7 & 3 \\
\hline UK & 39.8 & 21.1 & 19.2 & 28.1 & 84.4 & 2 \\
\hline Canada & 43.0 & 21.7 & 21.9 & 65.2 & 130.4 & 3 \\
\hline US & 32.5 & 16.8 & 16.8 & 37.8 & 75.6 & 1 \\
\hline Japan & 28.8 & 9.5 & 16.9 & 0.9 & 2.2 & 2 \\
\hline \multicolumn{7}{|c|}{ Small countries } \\
\hline Austria & 45.9 & 18.5 & 26.4 & 97.2 & 256.6 & 3 \\
\hline Belgium & 50.5 & 15.4 & 36.6 & 81.8 & 208.3 & 2 \\
\hline Denmark & 55.9 & 26.0 & 30.3 & 56.0 & 190.1 & 3 \\
\hline Finland & 33.0 & 20.4 & 12.7 & 73.5 & 194.5 & 3 \\
\hline Greece & 37.9 & 13.8 & 27.0 & 100.0 & 243.3 & 3 \\
\hline Ireland & 37.4 & 16.3 & 21.6 & 30.0 & 69.7 & 2 \\
\hline Netherlands & 51.6 & 15.3 & 36.7 & 72.1 & 179.1 & 2 \\
\hline Norway & 46.9 & 19.8 & 23.5 & 85.5 & 247.3 & 4 \\
\hline Portugal & 36.3 & 15.7 & 21.6 & 27.2 & 128.8 & 2 \\
\hline Sweden & 59.8 & 27.6 & 31.8 & 87.2 & 257.3 & 4 \\
\hline Switzerland & 32.4 & 13.7 & 17.5 & 54.4 & 164.6 & 2 \\
\hline Average & 42.2 & 17.9 & 24.5 & 61.3 & 164.9 & 2.5 \\
\hline Average SC & 44.3 & 18.4 & 26.0 & 69.5 & 194.5 & 2.7 \\
\hline
\end{tabular}

Sources and notes:

${ }^{1}$ Public Sector Size: average of overall government revenue and expenditure for 1980, 1990 and 1996, \% of GDP. Source: OECD, National Accounts, several years.

${ }^{2}$ Government Final Expenditure for 1980, 1990 and 1996 as \% of GDP. Source: OECD, National Accounts, several years

${ }^{3}$ Other Public Expenditure for 1980, 1990 and 1996 as \% of GDP. Source: OECD, National Accounts, several years.

${ }^{4}$ Left \%: Percentage of years in power of Left and Left-Centre parties. Source: Schmidt (1996).

${ }^{5}$ Left index: additive index of orientation of party in government: $3(\%$ left $)+2(\%$ left-centre $)+\%$ centre. Source: Schmidt (1996)

${ }^{6} \mathrm{~L} / \mathrm{R}$ scale: left-right scale of government. A higher number indicates governments more oriented towards the left. Source: Schmidt (1996) 
Table 5. Coefficient of correlation between the decentralisation index and regional inequality

\begin{tabular}{|l|c|c|c|c|c|c|c|c|c|}
\hline & \multicolumn{5}{|c|}{ Political Decentralisation } & \multicolumn{3}{c|}{ Fiscal Decentralisation } \\
\hline & Federal & CS & Lijphart & IP & IC & FiscDif & FiscDec & FiscCen & Fin Aut \\
\hline Sigma & -0.222 & -0.095 & 0.139 & 0.067 & -0.121 & -0.007 & $-0.471^{* *}$ & 0.254 & $-0.611^{* * *}$ \\
\hline Gini & -0.243 & -0.150 & 0.178 & 0.056 & -0.176 & -0.024 & $-0.399^{*}$ & 0.274 & $-0.558^{* *}$ \\
\hline Theil & -0.135 & 0.024 & 0.050 & 0.148 & -0.056 & 0.061 & $-0.402^{*}$ & 0.142 & $-0.597 * * *$ \\
\hline A(1) & -0.304 & -0.219 & 0.200 & -0.018 & -0.232 & -0.055 & $-0.504^{* *}$ & 0.253 & $-0.625^{* * *}$ \\
\hline A(3) & -0.286 & -0.163 & 0.171 & 0.036 & -0.192 & -0.012 & $-0.488^{* *}$ & 0.260 & $-0.612^{* * *}$ \\
\hline A(21) & -0.142 & 0.020 & 0.001 & 0.139 & -0.036 & 0.163 & -0.326 & 0.165 & $-0.403^{*}$ \\
\hline Average & -0.222 & -0.097 & 0.123 & 0.071 & -0.136 & 0.021 & -0.432 & 0.225 & -0.568 \\
\hline & & & & Small Countries & & & & \\
\hline Sigma & -0.093 & -0.278 & 0.364 & -0.175 & -0.053 & -0.211 & $-0.614^{* *}$ & $0.546 *$ & $-0.761 * * *$ \\
\hline Gini & -0.078 & -0.308 & 0.324 & -0.080 & -0.062 & -0.171 & -0.451 & 0.486 & $-0.638^{* *}$ \\
\hline Theil & -0.106 & -0.293 & 0.339 & -0.157 & -0.113 & -0.188 & $-0.574^{*}$ & 0.482 & $-0.774 * * *$ \\
\hline A(1) & -0.109 & -0.294 & 0.348 & -0.160 & -0.111 & -0.186 & $-0.584^{*}$ & 0.497 & $-0.774 * * *$ \\
\hline A(3) & -0.116 & -0.294 & 0.367 & -0.170 & -0.107 & -0.184 & $-0.607 * *$ & $0.531^{*}$ & $-0.773^{* * *}$ \\
\hline A(21) & -0.076 & -0.074 & 0.367 & -0.250 & -0.007 & -0.046 & $-0.686^{* *}$ & $0.569 *$ & $-0.704^{* *}$ \\
\hline Av. SC & -0.096 & -0.257 & 0.352 & -0.165 & -0.075 & -0.164 & -0.586 & 0.518 & -0.737 \\
\hline
\end{tabular}

*: significant at $10 \%, * *$ : significant at $5 \%$; ***: significant at $1 \%$ 
Table 6. Correlation between public sector size, parties in government and regional inequality indices.

\begin{tabular}{|l|c|c|c|c|c|c|}
\hline & PSS & GFE/GDP & OPE/GDP & Left $\%$ & Left index & L/R scale \\
\hline Sigma & -0.342 & $-0.418^{*}$ & -0.122 & $-0.449^{*}$ & $-0.443^{*}$ & -0.326 \\
\hline Gini & -0.318 & -0.326 & -0.168 & $-0.544^{*} *$ & $-0.482^{*} *$ & -0.306 \\
\hline Theil & -0.326 & -0.375 & -0.129 & $-0.476^{* *}$ & $-0.458^{*}$ & -0.417 \\
\hline A(1) & -0.264 & $-0.396^{*}$ & -0.045 & $-0.437^{*}$ & -0.386 & -0.266 \\
\hline A(3) & -0.332 & $-0.426^{*}$ & -0.106 & $-0.460^{*} *$ & $-0.438^{*}$ & -0.295 \\
\hline A(21) & $-0.497 * *$ & $-0.498^{*}$ & -0.254 & -0.353 & $-0.454^{*}$ & -0.211 \\
\hline Average & -0.347 & -0.406 & -0.137 & -0.453 & -0.444 & -0.304 \\
\hline & & & & & \\
\hline Sigma & -0.279 & -0.346 & -0.086 & -0.376 & -0.305 & -0.295 \\
\hline Gini & -0.256 & -0.204 & -0.164 & $-0.530 *$ & -0.380 & -0.295 \\
\hline Theil & -0.248 & -0.306 & -0.071 & -0.394 & -0.282 & -0.293 \\
\hline A(1) & -0.264 & -0.316 & -0.084 & -0.414 & -0.307 & -0.303 \\
\hline A(3) & -0.297 & -0.340 & -0.109 & -0.445 & -0.356 & -0.322 \\
\hline A(21) & -0.510 & $-0.573 *$ & -0.203 & -0.339 & -0.419 & -0.346 \\
\hline Average & -0.309 & -0.347 & -0.120 & -0.417 & -0.341 & -0.309 \\
\hline
\end{tabular}

*: significant at $10 \%, * *$ : significant at $5 \%$; ***: significant at $1 \%$ 
Table 7. Regression analysis of regional inequality

\begin{tabular}{|c|c|c|c|c|c|c|c|}
\hline \multirow{2}{*}{\begin{tabular}{|l|}
$\begin{array}{l}\text { Depen. } \\
\text { var } \downarrow .\end{array}$ \\
$\mathrm{A}(1)$
\end{tabular}} & \multicolumn{2}{|c|}{ Decentralisation variable } & \multicolumn{2}{|c|}{$\begin{array}{l}\text { Party in government } \\
\text { public sector variables }\end{array}$} & \multirow{2}{*}{\begin{tabular}{|c|} 
Ad. $\mathrm{R}^{2}$ \\
$0.163(.093)$ \\
\end{tabular}} & \multirow{2}{*}{$\begin{array}{c}\begin{array}{c}\text { Structural } \\
\text { change }^{(1)}\end{array} \\
0.581\end{array}$} & \multirow{2}{*}{$\begin{array}{c}\text { Heteros }^{(2)} \\
0.782\end{array}$} \\
\hline & \multirow[t]{3}{*}{ Federal } & $-0.0019(.253)$ & LEFT & \begin{tabular}{|l}
$-0.48 E-4(.078)$ \\
\end{tabular} & & & \\
\hline & & $-0.0027(.122)$ & PSS & $-0.13 \mathrm{E}-3(.157)$ & $0.102(.164)$ & 0.561 & 0.653 \\
\hline & & $-0.0022(.18)$ & GFE & \begin{tabular}{|c|}
$-0.3 E-3(.086)$ \\
\end{tabular} & $0.155(.101)$ & 0.605 & 0.723 \\
\hline & \multirow[t]{3}{*}{ Lijphart } & \begin{tabular}{|l}
$0.72 \mathrm{E}-3(.378)$ \\
\end{tabular} & LEFT & \begin{tabular}{|l}
$-0.51 E-4(.063)$ \\
\end{tabular} & $0.134(.122)$ & 0.855 & 0.453 \\
\hline & & $0.001(.244)$ & PSS & \begin{tabular}{|l}
$-0.13 \mathrm{E}-3(.174)$ \\
\end{tabular} & $0.041(.278)$ & 0.705 & 0.326 \\
\hline & & $0.0011(.208)$ & GFE & \begin{tabular}{|c|}
$-0.35 E-3(.057)$ \\
\end{tabular} & $0.144(.112)$ & 0.675 & 0.365 \\
\hline & \multirow[t]{3}{*}{ IC } & $-0.5 \mathrm{E}-3(.307)$ & LEFT & \begin{tabular}{|l}
$-0.51 E-4(.062)$ \\
\end{tabular} & $0.149(.107)$ & 0.675 & 0.515 \\
\hline & & \begin{tabular}{|c|}
$-0.9 \mathrm{E}-3(.132)$ \\
\end{tabular} & PSS & \begin{tabular}{|l}
$-0.16 \mathrm{E}-3(.112)$ \\
\end{tabular} & $0.095(.175)$ & 0.638 & 0.397 \\
\hline & & \begin{tabular}{|c|}
$-0.8 \mathrm{E}-3(.129)$ \\
\end{tabular} & GFE & \begin{tabular}{|c|}
$-0.37 \mathrm{E}-3(.004)$ \\
\end{tabular} & $0.182(.078)$ & 0.626 & 0.205 \\
\hline & \multirow[t]{3}{*}{ FiscDec } & \begin{tabular}{|l}
$-0.12 \mathrm{E}-3(.017)$ \\
\end{tabular} & LEFT & \begin{tabular}{|c|}
$-0.5 \mathrm{E}-4(.036)$ \\
\end{tabular} & $0.366(.01)$ & 0.912 & 0.366 \\
\hline & & \begin{tabular}{|c|}
$-0.12 \mathrm{E}-3(.027)$ \\
\end{tabular} & PSS & $-0.1 \mathrm{E}-3(.234)$ & $0.234(.046)$ & 0.794 & 0.667 \\
\hline & & \begin{tabular}{|c|}
$-0.1 \mathrm{E}-3(.083)$ \\
\end{tabular} & GFE & \begin{tabular}{|l|l|}
$-0.18 \mathrm{E}-3(.297)$ \\
\end{tabular} & $0.218(.054)$ & 0.819 & 0.535 \\
\hline & \multirow[t]{3}{*}{ FinAut } & $-0.11 \mathrm{E}-3(.002)$ & LEFT & \begin{tabular}{|l}
$-0.48 \mathrm{E}-4(.026)$ \\
\end{tabular} & $0.502(.001)$ & 0.824 & 0.813 \\
\hline & & 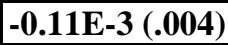 & PSS & \begin{tabular}{|c|}
$-0.1 \mathrm{E}-3(.194)$ \\
\end{tabular} & $0.385(.008)$ & 0.701 & 0.47 \\
\hline & & \begin{tabular}{|c|}
$-0.99 \mathrm{E}-4(.009)$ \\
\end{tabular} & GFE & $-0.2 \mathrm{E}-3(.195)$ & $0.384(.008)$ & 0.569 & 0.228 \\
\hline \multirow[t]{15}{*}{ Sigma } & \multirow[t]{3}{*}{ Federal } & $-0.0119(.445)$ & LEFT & \begin{tabular}{|c|}
$-0.47 E-3(.07)$ \\
\end{tabular} & $0.134(.122)$ & 0.716 & 0.797 \\
\hline & & \begin{tabular}{|c|}
$-0.0207(.202)$ \\
\end{tabular} & PSS & $\begin{array}{l}-0.0014(.095) \\
\end{array}$ & $0.106(.159)$ & 0.672 & 0.907 \\
\hline & & $-0.151(.329)$ & GFE & $-0.003(.075)$ & $0.127(.131)$ & 0.61 & 0.82 \\
\hline & \multirow[t]{3}{*}{ Lijphart } & $0.0048(.542)$ & LEFT & $0.5 \mathrm{E}-3(.059)$ & $0.123(.136)$ & 0.824 & 0.865 \\
\hline & & $0.0084(.313)$ & PSS & $-0.0015(.103)$ & $0.07(.218)$ & 0.66 & 0.678 \\
\hline & & $-0.008(.314)$ & GFE & $-0.0034(.054)$ & $0.131(.127)$ & 0.545 & 0.75 \\
\hline & \multirow[t]{3}{*}{ IC } & $-0.0025(.6)$ & LEFT & $-0.5 \mathrm{E}-3(.06)$ & $0.117(.143)$ & 0.818 & 0.743 \\
\hline & & $-0.0062(.252)$ & PSS & $-0.0017(.082)$ & $0.087(.188)$ & 0.729 & 0.969 \\
\hline & & $-0.0051(.306)$ & GFE & $\begin{array}{l}-0.0035(.051) \\
\end{array}$ & $0.133(.125)$ & 0.613 & 0.87 \\
\hline & \multirow{3}{*}{ FiscDec } & \begin{tabular}{|c|}
$-0.0011(.028)$ \\
\end{tabular} & LEFT & \begin{tabular}{|l}
$-0.49 \mathrm{E}-3(.035)$ \\
\end{tabular} & $0.341(.013)$ & 0.804 & 0.977 \\
\hline & & \begin{tabular}{|c|}
$-0.0011(.037)$ \\
\end{tabular} & PSS & \begin{tabular}{|c|}
$-0.0012(.121)$ \\
\end{tabular} & $0.249(.039)$ & 0.717 & 0.907 \\
\hline & & $-0.85 \mathrm{E}-3(.126)$ & GFE & $-0.002(.231)$ & $0.201(.064)$ & 0.671 & 0.811 \\
\hline & \multirow[t]{3}{*}{ FinAut } & 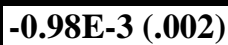 & LEFT & 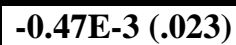 & $0.494(.001)$ & 0.69 & 0.85 \\
\hline & & $-0.001(.004)$ & PSS & \begin{tabular}{|c|}
$-0.0012(.086)$ \\
\end{tabular} & $0.417(.005)$ & 0.613 & 0.534 \\
\hline & & \begin{tabular}{|c|}
$-0.9 \mathrm{E}-3(.012)$ \\
\end{tabular} & GFE & $-0.0021(.155)$ & $0.381(.008)$ & 0.479 & 0.365 \\
\hline \multirow[t]{15}{*}{$\mathrm{A}(21)$} & \multirow[t]{3}{*}{ Federal } & \begin{tabular}{|l|}
$-0.0111(.667)$ \\
\end{tabular} & LEFT & $\begin{array}{l}-0.6 \mathrm{E}-3(.164) \\
\end{array}$ & $0.027(.313)$ & 0.372 & 0.439 \\
\hline & & $-0.0273(.253)$ & PSS & $-0.0032(.02)$ & $0.222(.052)$ & 0.452 & 0.411 \\
\hline & & \begin{tabular}{|c|}
$-0.0154(.518)$ \\
\end{tabular} & GFE & $\begin{array}{l}-0.0057(.033) \\
\end{array}$ & $0.176(.082)$ & 0.291 & 0.338 \\
\hline & \multirow[t]{3}{*}{ Lijphart } & $-0.8 \mathrm{E}-5(.999)$ & LEFT & $-0.62 \mathrm{E}-3(.15)$ & $0.015(.344)$ & 0.542 & 0.313 \\
\hline & & $0.0077(.534)$ & PSS & $\begin{array}{l}-0.0031(.028) \\
\end{array}$ & $0.174(.084)$ & 0.465 & 0.285 \\
\hline & & \begin{tabular}{|l|}
$0.0058(.636)$ \\
\end{tabular} & GFE & $\begin{array}{l}-0.006(.031) \\
\end{array}$ & $0.166(.091)$ & 0.275 & 0.218 \\
\hline & \multirow[t]{3}{*}{ IC } & $-0.0011(.886)$ & LEFT & $-0.62 \mathrm{E}-3(.15)$ & \begin{tabular}{|l}
$0.017(.34)$ \\
\end{tabular} & 0.458 & 0.376 \\
\hline & & 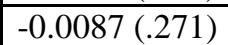 & PSS & \begin{tabular}{|c|}
$-0.0035(.017)$ \\
\end{tabular} & $0.217(.055)$ & 0.46 & 0.462 \\
\hline & & $-0.0057(.45)$ & GFE & $\begin{array}{l}-0.0062(.025) \\
\end{array}$ & $0.184(.076)$ & 0.254 & 0.48 \\
\hline & \multirow[t]{3}{*}{ FiscDec } & $-0.0012(.166)$ & LEFT & $-0.61 \mathrm{E}-3(.134)$ & \begin{tabular}{|l|}
$0.13(.128)$ \\
\end{tabular} & 0.395 & 0.643 \\
\hline & & \begin{tabular}{|l|}
$-0.0012(.136)$ \\
\end{tabular} & PSS & \begin{tabular}{|c|}
$-0.0029(.027)$ \\
\end{tabular} & $0.266(.032)$ & 0.467 & 0.12 \\
\hline & & $-0.6 \mathrm{E}-3(.487)$ & GFE & $-0.005(.075)$ & $0.18(.08)$ & 0.382 & 0.362 \\
\hline & FinAut & $-0.001(.087)$ & LEFT & \begin{tabular}{|l}
$-0.59 \mathrm{E}-3(.135)$ \\
\end{tabular} & $0.184(.076)$ & 0.409 & 0.943 \\
\hline & & $-0.001(.059)$ & PSS & \begin{tabular}{|c|}
$-0.0029(.022)$ \\
\end{tabular} & $0.327(.016)$ & 0.489 & 0.174 \\
\hline & & $-0.79 E-3(.175)$ & GFE & $-0.0049(.061)$ & $0.248(.039)$ & 0.361 & 0.443 \\
\hline
\end{tabular}

In parenthesis: significant level (derived from t and F statistics). In bold: significant at $10 \%$ level.

(1) Probability of the LM test for Structural Change (small countries/large countries). Large values indicate that we can't reject the null hypothesis

(2) Probability of the Breush-Pagan LM test for heteroskedasticity. Large values indicate that we can't reject the null hypothesis (homoskedasticity). 
Table 8. Regression analysis of regional inequality with decentralisation, public sector size and party in government (Left \%) for Small Countries

\begin{tabular}{|c|c|c|c|c|c|c|}
\hline $\begin{array}{l}\text { Depen. } \\
\text { var } \downarrow \text {. }\end{array}$ & \multicolumn{2}{|c|}{ Decentralisation variable } & \multicolumn{2}{|c|}{$\begin{array}{l}\text { Party in government or public } \\
\text { sector variable }\end{array}$} & Adjusted $\mathrm{R}^{2}$ & Heteros $^{(1)}$ \\
\hline \multirow[t]{6}{*}{$\mathrm{A}(1)$} & \multirow[t]{3}{*}{ FiscDec } & $-0.13 E-3(.075)$ & LEFT & $-0.43 \mathrm{E}-4(.23)$ & $0.32(.087)$ & 0.208 \\
\hline & & $-0.13 E-3(.085)$ & PSS & $-0.59 \mathrm{E}-4(.545)$ & $0.216(.155)$ & 0.276 \\
\hline & & $-0.14 \mathrm{E}-3(.125)$ & GFE & $-0.27 \mathrm{E}-5(.99)$ & $0.176(.188)$ & 0.251 \\
\hline & \multirow{3}{*}{ FinAut } & $-0.12 \mathrm{E}-3(.006)$ & LEFT & $-0.39 \mathrm{E}-4(.152)$ & $0.618(.008)$ & 0.622 \\
\hline & & -0.12E-3 (.009) & PSS & $-0.46 \mathrm{E}-4(.547)$ & $0.521(.021)$ & 0.36 \\
\hline & & $-0.13 E-3(.013)$ & GFE & $0.43 \mathrm{E}-4(.805)$ & $0.502(.025)$ & 0.384 \\
\hline \multirow[t]{6}{*}{ Sigma } & \multirow[t]{3}{*}{ FiscDec } & $-0.13 E-2(.059)$ & LEFT & $-0.35 \mathrm{E}-3(.284)$ & $0.331(.082)$ & 0.68 \\
\hline & & $-0.13 E-2(.065)$ & PSS & $-0.58 \mathrm{E}-3(.508)$ & $0.265(0.119)$ & 0.664 \\
\hline & & $-0.14 \mathrm{E}-2(.106)$ & GFE & $-0.15 \mathrm{E}-3(.944)$ & $0.222(.150)$ & 0.539 \\
\hline & \multirow[t]{3}{*}{ FinAut } & $-0.11 E-2(.008)$ & LEFT & $-0.32 \mathrm{E}-3(.225)$ & $0.567(.014)$ & 0.313 \\
\hline & & $-0.11 E-2(.011)$ & PSS & $-0.48 \mathrm{E}-3(.507)$ & $0.504(.024)$ & 0.932 \\
\hline & & $-0.12 E-2(.018)$ & GFE & $0.11 \mathrm{E}-3(.946)$ & $0.474(.031)$ & 0.944 \\
\hline \multirow[t]{6}{*}{$\mathrm{A}(21)$} & \multirow[t]{3}{*}{ FiscDec } & $-0.17 \mathrm{E}-2(.028)$ & LEFT & $-0.35 \mathrm{E}-3(.331)$ & $0.416(.047)$ & 0.424 \\
\hline & & $-0.17 E-2(.02)$ & PSS & $-0.15 E-2(.089)$ & $0.548(.017)$ & 0.898 \\
\hline & & $-0.14 \mathrm{E}-2(.101)$ & GFE & $-0.21 \mathrm{E}-2(.345)$ & $0.411(.0449)$ & 0.403 \\
\hline & \multirow[t]{3}{*}{ FinAut } & $-0.12 \mathrm{E}-2(.022)$ & LEFT & $-0.34 \mathrm{E}-3(.33)$ & $0.444(.039)$ & 0.885 \\
\hline & & $-0.11 E-2(.016)$ & PSS & $-0.15 E-2(.091)$ & $0.568(.014)$ & 0.553 \\
\hline & & $-0.1 \mathrm{E}-2(.066)$ & GFE & $-0.23 \mathrm{E}-2(.274)$ & $0.462(.343)$ & 0.726 \\
\hline
\end{tabular}

In parenthesis: significant level. In bold: significant at $10 \%$ level.

(1) Probability of the Breush-Pagan LM test for heteroskedasticity. Large values indicate that we can't reject the null hypothesis (homoskedasticity). 
Graph 1. Decentralisation (Financial Autonomy) and regional inequality (aggregate index)

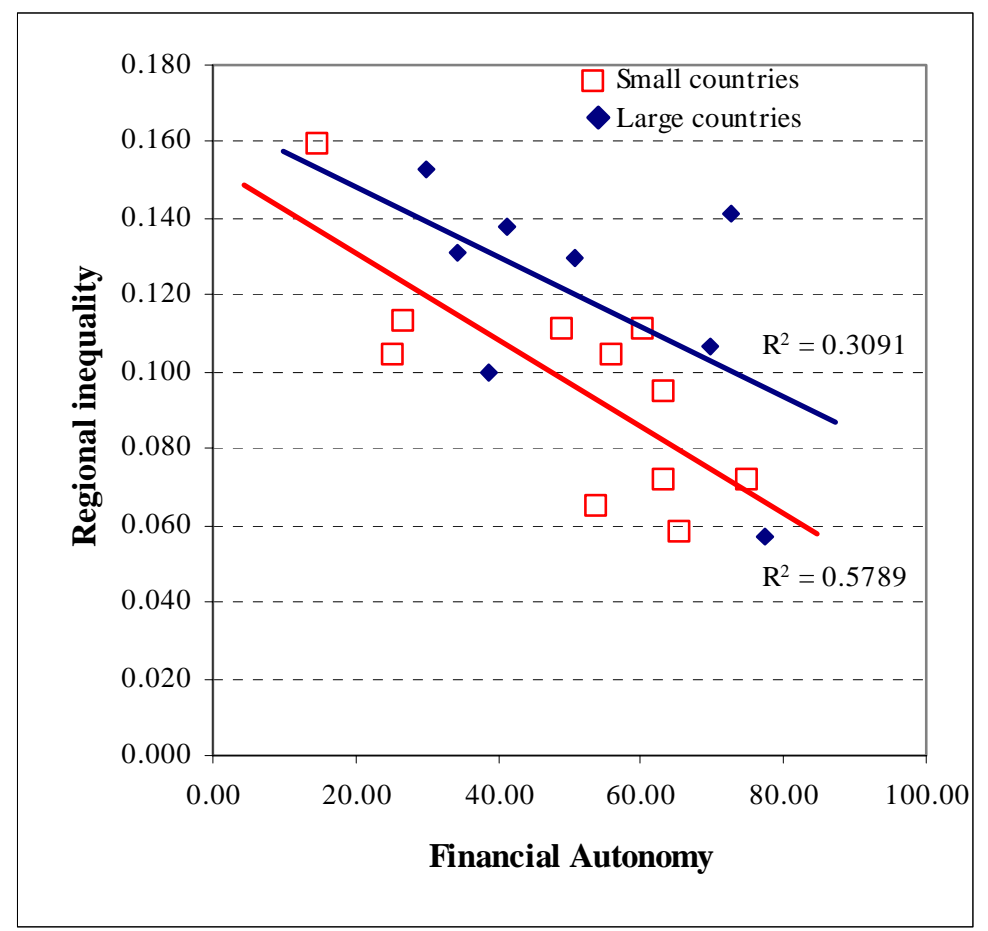

